\title{
Agricultural Productivity and Macro-Economic Variable Fluctuation in Nigeria
}

\author{
Sunday Brownson ${ }^{1}$, Ini-mfon Vincent ${ }^{1}$, Glory Emmanuel ${ }^{2} \&$ Daniel Etim $^{2}$ \\ ${ }^{1}$ Department of Agricultural Economics and Resources Management, Akwa Ibom state University, Ikot \\ Akpaden, Mkpat Enin, Akwa Ibom state, Nigeria \\ ${ }^{2}$ Department of Agricultural Economics and Extension, University of Uyo, Akwa Ibom State, Nigeria \\ Correspondence: Sunday Brownson, Department of Agricultural Economics and Resources Management, Akwa \\ Ibom state University, Ikot Akpaden, Mkpat Enin, P.M.B. 1167, Uyo, Akwa Ibom State, Nigeria. Tel: \\ 234-080-3672-8337. E-mail: sundayakpan10@yahoo.com
}

Received: May15, 2012

Accepted: June 29, 2012

Online Published: July 11, 2012

doi:10.5539/ijef.v4n8p114

URL: http://dx.doi.org/10.5539/ijef.v4n8p114

\begin{abstract}
The study established the empirical relationship between value of agricultural GDP as the ratio of total GDP (proxy as agricultural productivity) and some key macroeconomic variables in Nigeria. Augmented Dickey-Fuller unit root test and improved ADF-GLS unit root test conducted on the specified time series showed that all series were integrated of order one. The short-run and long-run elasticity of the agricultural productivity with respect to some key macro-economic variables were determined using the techniques of co-integration and error correction models. The empirical results revealed that in the short and long run periods, the coefficients of real total exports, external reserves, inflation rate and external debt have significant negative relationship with the agricultural productivity in the country; whereas industry's capacity utilization rate and nominal exchange rate have positive association with agricultural productivity in both periods. However, per capita real GDP influence on the agricultural productivity was positive and significant only in the ECM model. The empirical results were further substantiated by the variance decomposition and impulse response analysis of the dependent variable with respect to changes in the explanatory variables. Results obtained were in line with economic theory. The findings call for appropriate short and long term economic policy packages that should stimulate investment opportunities in the agricultural sector so as to increase agricultural component in the country's total export. Appropriate policy package to stabilize inflation rate in the country should be implemented. Also incentives should be given to the industrial sector to boast production in order to increase capacity utilization and promote backward integration policy of the sector. Diversification of the country's economy and a drastic reduction in external debt would boost agricultural productivity in the country.
\end{abstract}

Keywords: agricultural productivity, macroeconomic, variable, fluctuations, Nigeria

\section{Introduction}

Agricultural sector plays a vital role in the economy development of Nigeria. The agricultural sector contributes significantly to the gross domestic product (GDP) and employed about 86 percent of the rural households in the country (CBN, 2010; Fan et al., 2008 and Akpan, 2012). It is increasingly obvious that improvement in the agricultural development and growth can offer a pathway from rural poverty, but evidence-based macroeconomic policies and instruments are prerequisite. The country's agricultural policies and programmes over the years have been inconsistent, poorly implemented and mostly emerged as ad hoc attempts. Such agricultural policies have stunted the realization of the sector's full potentials. A paradigm shift towards a sound evidence-based policies anchored on sound macroeconomic policies is needed to promote a more equitable and environmental sustainable growth in the agricultural sector. According to the Central Bank of Nigeria (2006), the agricultural sector accounted for about 41.8 percent of the overall growth of the economy in 2006 followed by the non-oil industry (26.1 percent), while crude oil only accounted for 21.9 percent. But until very recently, the sector had not performed as well as it should have, because of several decades of neglect mostly accredited to the misalignment of economic policies in the country. From 1970 to 2000, the sector's productivity grew at 1.7 percent per annum, very low when compared with the country's population growth rate of about 2.7 percent per annum $(\mathrm{CBN}, 2010)$. This is one of the key reasons why the country still has one of the highest poverty rates in 
the world. Agricultural growth began to accelerate after 2000, and since 2003, the annual growth rate has been above the 6 percent mark, a target set under the National Empowerment and Economic Development Strategy (NEEDS) which is a poverty reduction programme founded in 2004. Agricultural policies under NEEDS were basically designed to allow certain level of protection to domestic investors. Concretely, the policies were translated into tariff escalation and lower import duties on raw materials and relatively high import duties on finished goods which compete with local production. Duty exemptions and concessions were some of the quantitative policy instrument adopted in favour of domestic producers. Despite the macroeconomic incentives to the agricultural sector, the agricultural GDP witnessed a negative growth rate of about $-28.21 \%$ between 2004 and 2005. However, following the marginal increase in the agricultural output in recent years, many economic analysts have attributed the growth to the expansion in cultivated land which has implication on the sustainability and environment deterioration in the long run (Akinbile and Adekunle, 2000, Okiki et al., 2001, Raufus, 2010 and Udoh et al., 2011). In addition, this growth has not been able to trickle down to the poorest of the poor, and has not helped tackle the problem of unemployment and underemployment of the rural youth (Fan et al., 2008 and Akpan, 2010).

Table 1. Macroeconomic variable fluctuations in various policy regimes in Nigeria.

\begin{tabular}{|c|c|c|c|c|c|c|c|}
\hline \multirow[b]{2}{*}{ INDICATOR } & \multicolumn{7}{|c|}{ Policy periods } \\
\hline & $\stackrel{1}{\circ} \stackrel{n}{2}$ & $\begin{array}{l}1 \\
\stackrel{1}{2}\end{array}$ & $\begin{array}{ll}\dot{1} & n \\
\stackrel{\infty}{a} & \infty\end{array}$ & $\begin{array}{l}\dot{1} \\
\stackrel{2}{\circ}\end{array}$ & $\stackrel{1}{2} \check{2}$ & ๖े ஓ̊ & $\underset{\text { 월 }}{\stackrel{1}{8}}$ \\
\hline Inflation rate $(\%)$ & 14.3 & 13.0 & 19.4 & 20.5 & 48.9 & 12.3 & 15.7 \\
\hline Official Exchange rate (N/\$) & 0.66 & 0.69 & 0.77 & 5.90 & 19.16 & 54.78 & 127.84 \\
\hline External Reserve $(\mathrm{Ab})$ & 1.19 & 3.06 & 1.40 & 11.98 & 39.2 & 361.6 & 1869.7 \\
\hline Index of Energy Consumption $(1985=100)$ & 26.3 & 64.6 & 122.8 & 95.6 & 95.7 & 83.3 & 167.4 \\
\hline Real GDP per capita ( $N /$ person) $(1985=100)$ & 177.2 & 735 & 3.25 & 962 & 674 & 547 & 819 \\
\hline Real FPI in Manu. and Processing ( $(\mathrm{b})$ & 2.79 & 3.17 & 2.74 & 2.20 & 1.53 & 1.09 & 1.26 \\
\hline Index of Agricultural Production $(1990=100)$ & 65.62 & 56.44 & 58.74 & 79.20 & 121.6 & 141.5 & 158.2 \\
\hline Index of Manufacturing Production $(1985=100)$ & 32.85 & 75.42 & 105.7 & 135.4 & 154.7 & 137.2 & 145.6 \\
\hline Non oil export ( $\mathrm{Am})$ & 358.4 & 574.9 & 328.4 & 2335.1 & 8468.3 & 26175.4 & 87356.4 \\
\hline Av. Industry Capacity Utilization Rate (\%) & 76.6 & 71.12 & 53.58 & 41.14 & 35.40 & 33.59 & 46.18 \\
\hline
\end{tabular}

Source: Computed by authors, data from Central Bank of Nigeria Statistical Bulletin (2010)

Usually several factors can be said to be responsible for the gloomy performance of the Nigerian agricultural sector. Paramount among these factors is the uncertainty in the macroeconomic environment as presented in Table 1. The macroeconomic environment consists of the fiscal, monetary, exchange rate regimes and trade policies among other policies tended to regulate production activities in the real sectors and other sectors including the agricultural sector. Regrettably, macroeconomic policy outcomes in any economy vary greatly depending in part on the policy targets and instruments employed as well as operating environment (Agu, 2007). Sound macroeconomic policies are important to achieve national development targets through agricultural development (Fan et al., 2008). Macroeconomic variables have serious economic and development implication for the sustenance of agricultural production and stimulation of export. Trade Import restrictions and trade barriers lead to less efficient use of scarce resources. Oil exports have led to large foreign exchange inflows. In turn, the foreign exchange inflows have not only depreciated the value of Nigeria's currency but have also eroded the competitiveness of domestic produced agricultural goods in comparison with low-priced imported goods, leading to a reduction in agricultural activities in the country (Fan et al., 2008). The exchange rate regime adopted during the Structural Adjustment Programme (SAP) neither has not resulted in any meaningful export of agricultural produce over time (Table 1). For instance, in 1993 agricultural export amounted to only 1.7 percentage of the total export in the country (CBN, 2010). More must be done to ensure a favorable macroeconomic environment for pro-poor investments and growth. Many authors (Binswanger, 1989; Kwanashie and Ajilima, 1997 and Killick, 1990) have reported the influenced of macroeconomic variables fluctuations on the agricultural productivity. In Nigeria, Garba (2000) and Akpokodje, (2000) confirmed that 
major macroeconomic policy shifts heighten agricultural policy instability in the country. Eyo (2008) established empirical linkages between macro economic growth and agricultural productivity in Nigeria. His results revealed that the exchange rate regime (-ve), nominal interest rate $(+v e)$, government expenditure $((+v e)$ and foreign private investment $((+v e)$ in agricultural have significant effects on the index of agricultural output in Nigeria. This study differs from Eyo (2008) study because different measure of agricultural productivity is used and more reliable time series analysis is employed as well as extended macroeconomic variables in the model. Shombe (2008) in Tanzania discovered two-way causality relationship between agricultural GDP and total exports, and a one way causality relationship among manufacturing, export and agricultural GDP. In Cote d'voire and Zimbabwe, Bulanch and Verner, (2006), empirically supported the existence of the positive growth links between agriculture and industry. Memonet al., (2008) found bi-directional Granger-causality relationship between total exports and agricultural GDP in the case of Pakistan.Hye and Zameer (2011) in Pakistan showed a significant positive long run relationship between trade openness and the real agricultural growth. While Salih (2006), present empirical evidence showing a significant long run relationship between agricultural output growth and economic growth that assumes bidirectional causation. It therefore implies that, the resilience of the agricultural sector depends largely on the level of economic growth in the country which is largely hinged on the stability of some key macroeconomic fundamentals. Therefore, this study specifically established the short and the long run links between agricultural productivity and some key macroeconomic fundamentals in the country. Such relationship is momentous and is a reliable tool needed to accelerate productivity in the agricultural sector in the country. The result of this study provides an alternative policy area that could be used to accelerate the sluggish growth rate in the agricultural sector in the country.

\section{Research Methodology}

\subsection{Study Area and Data Source}

The study was conducted in Nigeria; the country is situated on the Gulf of Guinea in the sub Saharan Africa. Nigeria lies between $4^{0}$ and $14^{\circ}$ north of the equator and between longitude $3^{0}$ and $15^{\circ}$ east of the Greenwich. Nigeria has a total land area of 923,768. 622 squared kilometers and a population of over 140 million (NPC, 2006). Secondary data derived from publications of the Central Bank of Nigeria (CBN) and National Bureau of Statistics was used in the analysis. Data covered the period 1970 to 2010.

\subsection{Analytical Techniques}

Agricultural productivity equation wasspecified based on the objective of the study as follows:

$$
\begin{gathered}
L n A G D_{t}=\delta_{0}+\delta_{1} L n E X P_{t}+\delta_{2} L_{n E X R_{t}}+\delta_{3} \operatorname{LnINF}_{t}+\delta_{4} L n P C R_{t}+\delta_{5} L n C U R_{t}+\delta_{6} L n E X D_{t}+\delta_{7} \operatorname{LnINR}_{t}+\delta_{8} L n S A V_{t}+\delta_{9} L_{n} O I L_{t} \\
+\delta_{10} L n E X C_{t}+U_{t}
\end{gathered}
$$

Where;

$\mathrm{AGD}_{\mathrm{t}}=$ Agricultural GDP as a ratio of total GDP (Used as a proxy for agricultural productivity)

$\mathrm{EXPt}=$ real value of total export $(\mathrm{Nm})$

$\mathrm{EXR}_{\mathrm{t}}=$ real external reserves $(\mathrm{Nm})$

$\mathrm{INF}_{\mathrm{t}}=$ inflation rate $(\%)$

$\mathrm{PCR}_{\mathrm{t}}=$ real per capita GDP as a proxy of aggregate demand shock ( $\mathrm{N} /$ person)

$\mathrm{CUR}_{\mathrm{t}}=$ industry's capacity utilization rate $(\%)$

$\mathrm{EXD}_{\mathrm{t}}=$ external debt as a ratio of GDP

$\mathrm{INR}_{\mathrm{t}}=$ interest rate (lending rate)

$\mathrm{SAV}_{\mathrm{t}}=$ domestic saving as a ratio of GDP

$\mathrm{OILt}=$ oil revenue as a ratio of GDP

$\mathrm{EXC}_{\mathrm{t}}=$ nominal exchange rate

$U_{t}=$ stochastic error term and $U_{t} \sim \operatorname{IID}\left(0, \delta_{\mathrm{U}}^{2}\right)$.

Consumer price index $(2003=100)$ was used to convert the nominal values to real values.

\section{Results and Discussion}

\subsection{Unit Root Test}

In time series analysis, stationarity of the series is examined by the unit root tests. One of the most commonly used tests in the literature to ascertain the stationarity level of series are ADF test developed by Dickey and 
Fuller in (1979) and ADF-GLS unit root test developed by Elliott, Rothenberg and Stock in (1996) which is an improvement of the original ADF test. These two tests were used in this study for determining the stationarity level of series. PC-Give 10 and gretl econometric softwares were used to carry out the tests and the result is presented in Table 2. The result for both ADF and ADF-GLS unit root tests show that most specified variables were non stationary at levels but stationary at the first difference. However, the ADF-GLS unit root test (without trend) shows that all variables were non stationary at level. The result implies that the time series should be tested for the existence of cointegration among them (Johansen, 1988 and Johansen and Juselius, 1990).

Table 2. ADF and ADF-GLS unit root teston variables explained in equation 1

\begin{tabular}{|c|c|c|c|c|c|c|c|c|c|c|c|c|}
\hline \multirow[b]{3}{*}{ Logged Variables } & \multicolumn{6}{|c|}{ ADF unit root test } & \multicolumn{6}{|c|}{ ADF-GLS unit root test } \\
\hline & \multicolumn{3}{|c|}{ With Trend } & \multicolumn{3}{|c|}{ Without Trend } & \multicolumn{3}{|c|}{ With Trend } & \multicolumn{3}{|c|}{ Without Trend } \\
\hline & level & 1 st diff. & OT & level & 1st diff. & OT & level & 1st diff. & OT & level & 1st diff. & OT \\
\hline AGD & -3.49 & $-7.03 *$ & 1(1) & -1.81 & $-6.80 *$ & 1(1) & -2.21 & $-7.21 *$ & $1(1)$ & -1.47 & $-6.57^{*}$ & $1(1)$ \\
\hline EXP & -2.90 & $-7.83^{*}$ & $1(1)$ & -1.96 & $-7.94 *$ & $1(1)$ & -2.89 & $-7.67 *$ & $1(1)$ & -1.19 & $-7.03 *$ & $1(1)$ \\
\hline EXR & -2.60 & $-6.46^{*}$ & $1(1)$ & -1.87 & $-6.55^{*}$ & 1(1) & -2.62 & $-6.62 *$ & $1(1)$ & -1.25 & $-6.62 *$ & $1(1)$ \\
\hline INF & -3.85 & $-6.81 *$ & 1(1) $1(1)$ & $-3.98 *$ & - & $1(0)$ & -3.26 & $-6.95^{*}$ & $1(1)$ & -2.44 & $-6.85^{*}$ & $1(1)$ \\
\hline PCR & -1.96 & $-6.04 *$ & $1(1)$ & -2.43 & $--5.71 *$ & 1(1) & -1.56 & $-6.11 *$ & $1(1)$ & -0.45 & $-5.78 *$ & $1(1)$ \\
\hline CUR & -0.69 & $-4.02 *$ & $1(1)$ & -1.24 & $-3.95 *$ & 1(1) & -0.85 & $-4.11 *$ & $1(1)$ & -0.98 & $-4.00 *$ & $1(1)$ \\
\hline EXD & -0.98 & $-5.99 *$ & $1(1)$ & -1.41 & $-5.79 *$ & 1(1) & -1.23 & $-6.03 *$ & $1(1)$ & -1.33 & $-5.82 *$ & 1(1) \\
\hline INR & -1.91 & $-8.72 *$ & $1(1)$ & -1.62 & $-8.70^{*}$ & 1(1) & -2.05 & $-8.91 *$ & $1(1)$ & -1.19 & $-8.78 *$ & 1(1) \\
\hline SAV & -1.67 & $-5.65^{*}$ & $1(0)$ & -1.68 & $-5.79 *$ & $1(1)$ & -1.73 & $-5.71 *$ & $1(1)$ & -1.54 & $-5.51 *$ & 1(1) \\
\hline OIL & $-6.24 *$ & - & $1(1)$ & $-5.52 *$ & - & $1(0)$ & -4.29 & - & $1(0)$ & -2.19 & $-5.80^{*}$ & $1(1)$ \\
\hline EXC & -2.60 & $-5.05^{*}$ & $1(0)$ & 0.03 & $-5.11^{*}$ & $1(1)$ & -1.58 & $-5.17 *$ & $1(1)$ & 0.76 & $-4.92 *$ & 1(1) \\
\hline Residual & $-5.38^{*}$ & - & & $-5.46^{*}$ & - & $1(0)$ & $-5.49 *$ & - & $1(0)$ & $-5.42 *$ & - & $1(0)$ \\
\hline $1 \%$ & 4.20 & -4.21 & & -3.60 & -3.61 & & -3.77 & 3.77 & & & & \\
\hline
\end{tabular}

Note: OT means order of integration. Critical value (CV) is defined at $1 \%\left(^{*}\right)$ probability level. Variables are as defined in equations (1) and are expressed in log.

\subsection{Cointegration Test}

The concept of cointegration as developed by Granger (1981) involved the determination of the static or long-run associations among non-stationary time series. The pre-condition for applying the standard procedure of the cointegration tests to any series is that the variables in consideration must be integrated of the same order or non-stationary individually. The study applied the Engle and Granger two-step technique and Johansen cointegration approach to examine cointegration relationship among time series. 
Table 3. Results of Johansen Cointegration Test (unrestricted constant)

\begin{tabular}{llllll}
\hline Rank & Eigen value & Trace Test & P-value & Lmax. Test & P-value \\
\hline $\mathbf{0}$ & 0.972 & 499.31 & {$[0.000]$} & 139.02 & {$[0.000]$} \\
$\mathbf{1}$ & 0.909 & 360.29 & {$[0.000]$} & 93.60 & {$[0.000]$} \\
$\mathbf{2}$ & 0.773 & 266.68 & {$[0.000]$} & 57.86 & {$[0.052]$} \\
$\mathbf{3}$ & 0.760 & 208.83 & {$[0.000]$} & 55.73 & {$[0.017]$} \\
$\mathbf{4}$ & 0.696 & 153.09 & {$[0.000]$} & 46.41 & {$[0.044]$} \\
$\mathbf{5}$ & 0.601 & 106.69 & {$[0.006]$} & 35.84 & {$[0.141]$} \\
$\mathbf{6}$ & 0.509 & 70.85 & {$[0.039]$} & 27.77 & {$[0.231]$} \\
$\mathbf{7}$ & 0.380 & 43.09 & {$[0.131]$} & 18.66 & {$[0.454]$} \\
$\mathbf{8}$ & 0.304 & 24.42 & {$[0.189]$} & 14.17 & {$[0.365]$} \\
$\mathbf{9}$ & 0.193 & 10.25 & {$[0.267]$} & 8.35 & {$[0.352]$} \\
$\mathbf{1 0}$ & 0.048 & 1.899 & {$[0.168]$} & 1.89 & {$[0.168]$} \\
\hline
\end{tabular}

Note: The null hypothesis of no cointegration is rejected at $1 \%$ probability level

The result of the Engle and Granger two-step technique of the cointegration regression and the stationarity tests for the residual (ECM) generated in equation 1 is presented in Table 2. The results show that at the $1 \%$ probability level of significance, the Engle-Granger cointegration tests reject the null hypothesis of no cointegration. Hence, there exists a long run equilibrium relationship between the agricultural productivity and some major macroeconomic variables in Nigeria. For the Johansen cointegration approach, the trace and maximum eigenvalue test statistics were significant at various rank levels. The result as presented in Table 3 means that the calculated trace test and maximum eigenvalue test statistics are greater than the critical values at $10 \%, 5 \%$ and $1 \%$ probability levels. This implies that there is cointegration relationship among the specified variables. Table 4 presents the long run estimates for the equation 1 . The estimated coefficients represent the agricultural productivity elasticity with respect to each specify macroeconomic variable.

Table 4. Long run equation for Agricultural productivity in Nigeria

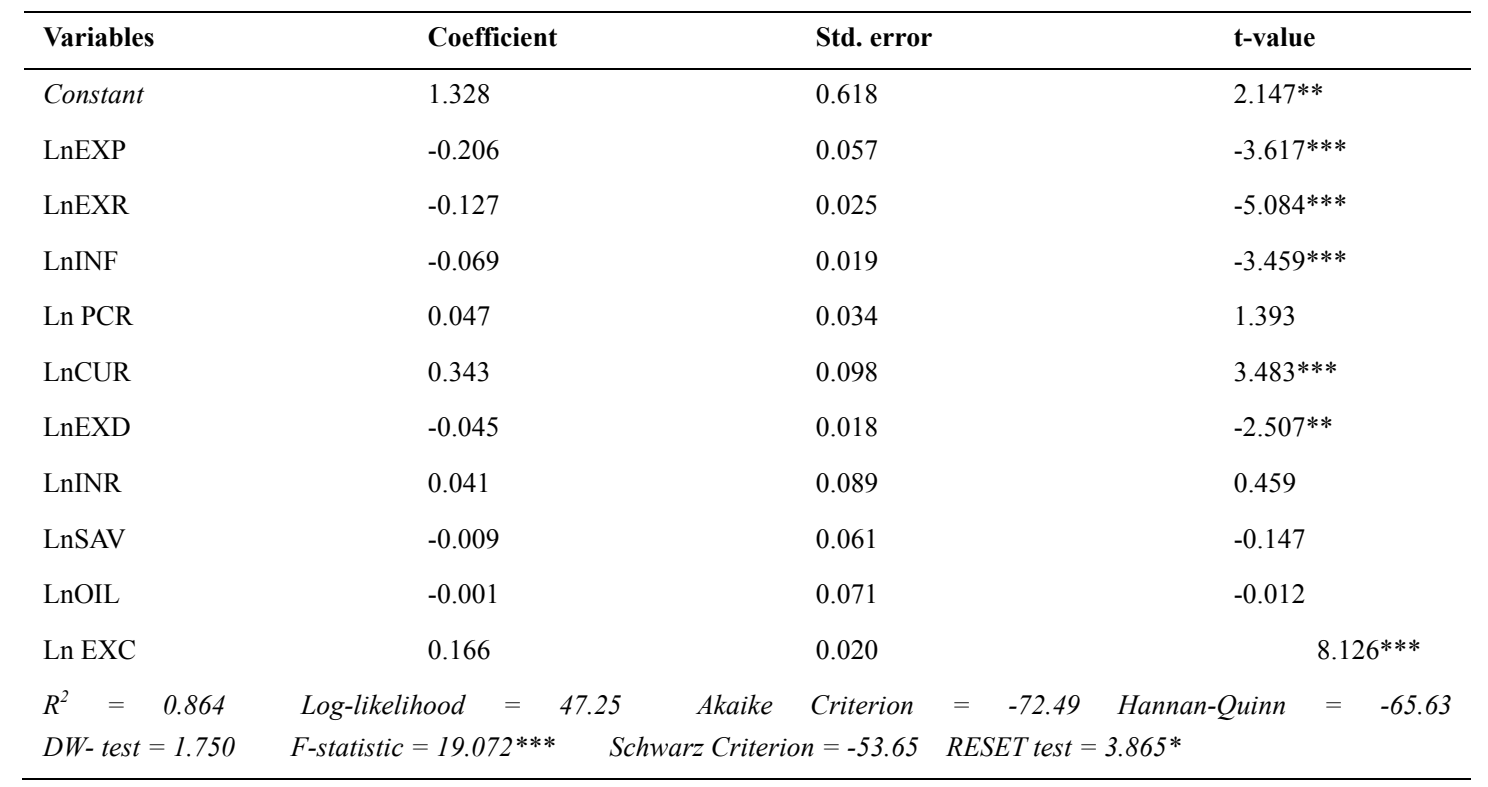

Note: Asterisks * and ** represent 10\% and 5\% significance levels respectively. Variables are as defined in equation (1).

\subsection{Generating Optimal Lag- Length for the Co-Integrating Variables}

Appropriate lag length for the co-integrating series is needed to generate the error correction model (ECM) for 
the specified equation (i.e. equation 2). The following information criteria were used to select appropriate lag length for the co-integrating series: there are Akaike criterion (AIC), Schwarz Bayesian criterion (BIC) and Hannan- Quinn criterion (HQC). The test result as shown in Table 5 indicates that the optimum lag length appropriate for the specified variables is at the second lag indicated by asterisks in AIC and HQC information criterion. The lag length that minimizes the information criteria is 2 . This means that in generating the short run dynamic model for agricultural productivity with respect to key macroeconomic variables in Nigeria, the optimum lag length of time series should be kept at 2 in order to obtain a more interpretable parsimonious ECM model.

Table 5. Optimal lag length of variables used in the analysis

\begin{tabular}{llllll}
\hline Lags & loglike & $\mathrm{p}(\mathrm{LR})$ & AIC & BIC & HQC \\
\hline $\boldsymbol{1}$ & 105.09 & 0.000 & 1.380 & $7.011^{*}$ & 3.400 \\
$\mathbf{2}$ & 272.58 & 0.000 & $-1.004^{*}$ & 9.787 & $2.868^{*}$ \\
\hline
\end{tabular}

Note: Asterisk means optimum lag length.

\subsection{Error Correction Model for Agricultural Productivity in Nigeria}

Following the Granger Representation Theorem, we specify the ECM model for the co-integrating series in the study. The primary reason for estimating the ECM model is to capture the dynamics in the agricultural productivity equation in the short-run and to identify the speed of adjustment as a response to departures from the long-run equilibrium. The general specification of the ECM that was estimated for the agricultural productivity in Nigeria is shown below:

$$
\Delta \operatorname{Loan}_{t}=\delta_{0}+\delta_{1} \sum_{i=1}^{1} \Delta \operatorname{Loan}_{t-1}+\delta_{2} \sum_{j=1}^{1} \Delta X^{\prime} s_{t-1}+\delta_{3} E C M_{t-1}+\varepsilon_{1 t}
$$

The variables X's are as defined previously in equation (1) and the coefficient $\left(\boldsymbol{\delta}_{3}\right)$ of the $\operatorname{ECM}_{t-1}\left(-1<\boldsymbol{\delta}_{3}<0\right)$ measures the deviations from the long-run equilibrium in period $\left(\mathrm{t}_{-1}\right)$. In order to obtain a parsimonious dynamic ECM for the agricultural productivity equation, the study adopted Hendry's (1995) approach in which an over parameterized model is initially estimated and then gradually reduced by eliminating insignificant lagged variables until a more interpretable and parsimonious model is obtained. The result of the exercise is presented in Tables 6.

The slope coefficient of the error correction term is negative and statistically significant at $1 \%$ probability level. The result validates the existence of a long-run equilibrium relationship among the time series in the agricultural productivity equation, and also indicates that the agricultural productivity is sensitive to the departure from it equilibrium value in the previous periods. The slope coefficient of the error correction term (0.6076) represents the speed of adjustment and also is consistent with the hypothesis of convergence towards the long-run equilibrium once the agricultural productivity equation is shocked. The coefficient of $E C M_{t}$ suggests that in the absence of variation in the specified macroeconomic variables in the short run, that about 60.76 percent of the divergence between actual and equilibrium agricultural productivity is corrected annually in the country. 
Table 6. ECM estimates for equation of Agricultural Productivity in Nigeria

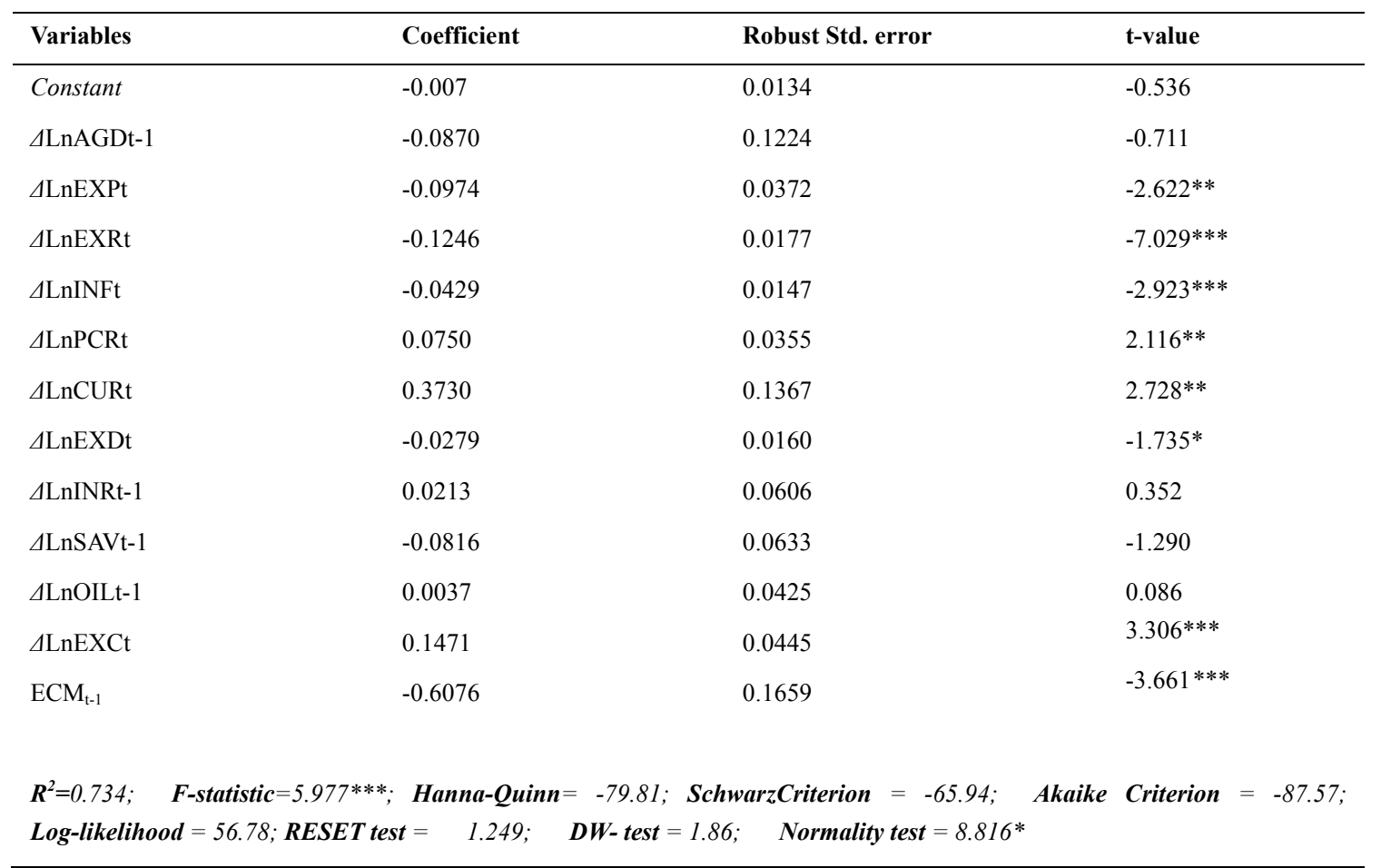

Note: Asterisks $* * *$ and $* * *$ represent $10 \%, 5 \%$ and $1 \%$ significance levels respectively. Variables are as defined in equation (1).

The diagnostic test for the ECM model revealed $\mathrm{R}^{2}$ value of 0.734 which means that the specified explanatory time series explained about $73.40 \%$ of the adjusted total variations in the agricultural productivity. The F-statistic of 5.977 is significant at $1 \%$ probability level, indicating that the $\mathrm{R}^{2}$ is significant and this implies that the equation has goodness of fit. The Durbin-Watson value of 1.86 however indicates that there exists a minor serial correlation. The ECM model has been shown to be robust against residual autocorrelation. Therefore, the presence of autocorrelation does not affect the estimates (Laurenceson and Chai, 2003).

The ECM model reveals that the agricultural productivity has a significant negative inelastic relationship with the real value of total export (EXP) in the country. The result is replicated in the long run period too. The reason for the result could be linked to the fact that; greater proportion of the country's exports is non-agriculture. As such increase in exports will means increase in non-agricultural based exports and consequently increase neglect of the agricultural sector in the country.

The slope coefficients of inflation both in the short and long run periods are negative and significant. This implies that agricultural productivity has a significant negative relationship with the rate of inflation in the country. The result satisfy the a priori expectation because increase in inflation will raise the price of agricultural commodities which could result in reduction in agricultural commodity demand and supply both in the short and long run periods.

The result also shows that the agricultural productivity has a significant negative inelastic correlation with the external reserve (EXR) in the country. It implies that as the country's external reserve increase, the agricultural productivity decreases. The result is however surprising; but we attempt to explain the cause of the outcome in two ways as follows: the first is that increase in external reserve will promote importation. This might introduced unhealthy competition in the domestic environment. As expected the infancy nature of our agricultural production activities will decline. The second reason is based on the fact that increase in the external reserve might indicate the present of insufficient investment opportunities in the real sector of the economy. This could be interpreted to mean that the productive sector might be producing below the optimum or frontier level and are not adequately generating investment opportunities to justify government financial investment. As a consequent, government as a policy could decide to save the excess revenue rather than injecting such in agriculture. This action has the tendency of decreasing the agricultural production in both periods.

In addition, increase in the real per capita income increases the agricultural productivity in both short and long 
run periods in the country. The relationship however was only significant in the short run period. The result is in line with the a priori expectation, as increase in PCI increases the purchasing power of the populace. This has a tendency to stimulate demand and supply of agricultural commodity in the country. The coefficient of industrial capacity utilization rate (CUR) is positive and statistically significant in both short and long run periods. This implies that $10 \%$ increase in the industrial capacity utilization rate, would result in about $37.30 \%$ and $34.30 \%$ increase in agricultural productivity in short and long run periods respectively. The finding suggests that the backward integration policy of the manufacturing sector in the country actually works. This means that agro based manufacturing sub sector to an extent depended on the raw materials from the domestic agricultural sector. The result reveals that there is an additional incentive to both foreign and domestic investors in the agricultural sector in the country.

Furthermore, the coefficient of external debt (EXD) has a significant negative association with the agricultural productivity both in the short and long run periods. The result corroborates the apriori expectation. This is because increase in EXD will likely induced deficit budget which could lead to under allocation of resources to other sectors in the economy. This would likely result in the decline in the productivity in some real sectors of the economy. In Nigeria, some aspect of our agricultural production is still enjoying some form of subsidies from the governments. The subsidy programme can only be sustained if the economy is self reliance. Continuous borrowing to finance development in the real sector especially the agricultural sector might not lead to sustain productivity in the country. This is due to the fact that our technology is still at the infancy level and agricultural sector dominated by small scale farmers. Finally, the agricultural productivity has a positive inelastic influenced on the nominal exchange rate (EXC) in both periods. This means that increase in the nominal exchange rate increases the agricultural productivity in the country. The possible reason for the result is that increase in the nominal exchange rate ( $\$$ ) will constrain importation by depreciating the domestic currency ( $)$ against appreciating US dollar. The reduced importation decrease unhealthy competition at the domestic environment and also creates incentives for farmers to increase productivity.

The causality test (using F-statistic) for both short and long run period models reveal that causality runs from macroeconomic variables to agricultural productivity (unidirectional). This means that total variation in agricultural productivity are induced by changes in macroeconomic variables

\subsection{Variance Decomposition of Agricultural Productivity (AGD)}

An examination of the variations in the agricultural GDP used as a proxy of agricultural productivity in both short and long run periods is further supplemented by the variance decomposition analysis results presented in Table 7. The result shows the relative contribution of various macroeconomic variables to the variation in the agricultural productivity. The result reveals that in the second period, industry capacity utilization (CUR), interest rate (INR) and oil revenue (OIL) were the major exogenous contributors to changes in the agricultural productivity (AGD). From the result, "own shocks" constitute a significant source of variation in agricultural productivity both in the short and long run forecast variance errors, over the 10 year horizon. In the long run, per capita real GDP, interest rate, and inflation rate are the major contributors to error variance in the agricultural productivity in the country. This result corroborates the findings earlier reported in the long and short run model analyses.

Table 7. Variance decomposition

\begin{tabular}{lllllllllllll}
\hline Period & S.E & AGD & CUR & INF & SAV & EXD & OIL & PCR & EXC & EXR & INR & EXP \\
\hline $\mathbf{1}$ & 0.10 & 100.00 & 0.00 & 0.00 & 0.00 & 0.00 & 0.00 & 0.00 & 0.00 & 0.00 & 0.00 & 0.00 \\
$\mathbf{2}$ & 0.14 & 96.13 & 0.84 & 0.24 & 0.03 & 0.01 & 0.48 & 0.17 & 0.10 & 0.11 & 0.83 & 0.06 \\
$\mathbf{3}$ & 0.16 & 94.89 & 1.12 & 0.18 & 0.15 & 0.01 & 0.37 & 1.92 & 0.39 & 0.13 & 0.75 & 0.07 \\
$\mathbf{4}$ & 0.19 & 94.79 & 0.99 & 0.27 & 0.11 & 0.04 & 0.28 & 2.01 & 0.32 & 0.13 & 0.99 & 0.06 \\
$\mathbf{5}$ & 0.21 & 94.56 & 0.80 & 0.53 & 0.09 & 0.04 & 0.25 & 2.19 & 0.26 & 0.13 & 1.09 & 0.05 \\
$\mathbf{6}$ & 0.23 & 94.37 & 0.69 & 0.62 & 0.09 & 0.04 & 0.24 & 2.44 & 0.22 & 0.13 & 1.12 & 0.04 \\
$\mathbf{7}$ & 0.25 & 94.17 & 0.64 & 0.67 & 0.08 & 0.03 & 0.22 & 2.64 & 0.19 & 0.13 & 1.19 & 0.03 \\
$\mathbf{8}$ & 0.27 & 94.01 & 0.58 & 0.74 & 0.07 & 0.04 & 0.20 & 2.78 & 0.16 & 0.14 & 1.24 & 0.03 \\
$\mathbf{9}$ & 0.28 & 93.88 & 0.53 & 0.81 & 0.07 & 0.04 & 0.19 & 2.90 & 0.15 & 0.14 & 1.27 & 0.03 \\
$\mathbf{1 0}$ & 0.29 & 93.77 & 0.49 & 0.85 & 0.07 & 0.04 & 0.18 & 3.00 & 0.14 & 0.14 & 1.29 & 0.02 \\
\hline
\end{tabular}

Source: Compiled by authors 
The analysis of variance decomposition shows that industrial capacity utilization rate, per capita real GDP and interest rate are the most important factors that affect agricultural productivity in both periods in Nigeria.

To complement the analysis on the Variance Decomposition analysis, we further generate the Impulse Response Functions, as described in figure 1 to 3 . Impulse Response Functions produced a time path of dependent variables attributed to shock from the explanatory variables. The result reveals that for the agricultural productivity, most shocks from the explanatory variables makes the impulse responses dies out to zero. This substantiates the fact that the system of equation developed in ECM and long run model, is a stable system. Furthermore, from figure1-3, the directions of agricultural productivity responses to innovations in the system are theoretically reasonable in most cases. The result reveals that a positive shock in the industrial capacity utilization stimulates agricultural productivity positively in both short and long run periods. However, the response seems to be consistent in the long run implying a stable relationship in the long run period. The result revalidates the earlier results reported in this study and agree with the economic thought given the fact that Nigeria over the years had promoted backward integration policy of the industrial sector to agricultural sector. The response of agricultural productivity to shock (increase) in external debt is negative in both short and long run periods. The response was close to zero in both short and long run periods implying a stable relationship in both time horizons. Also the response of agricultural productivity to changes (increase) in the real per capita income (PCR) is positive in all periods. The response took a sharp acceleration from period 1 to 3 and thereafter assumes almost constant fluctuations. However the response was further away from the origin signifying increasing instability in the long run period.

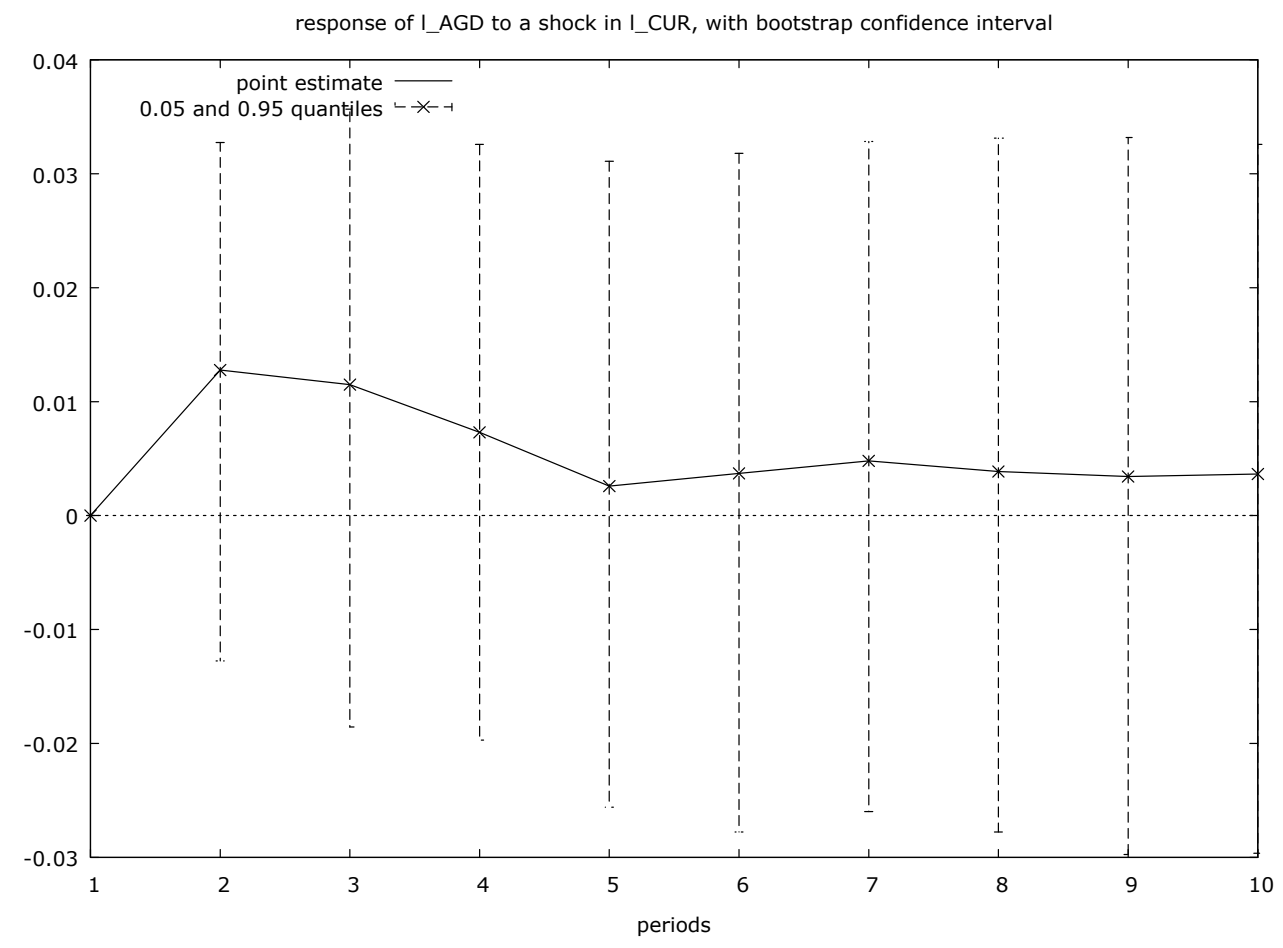



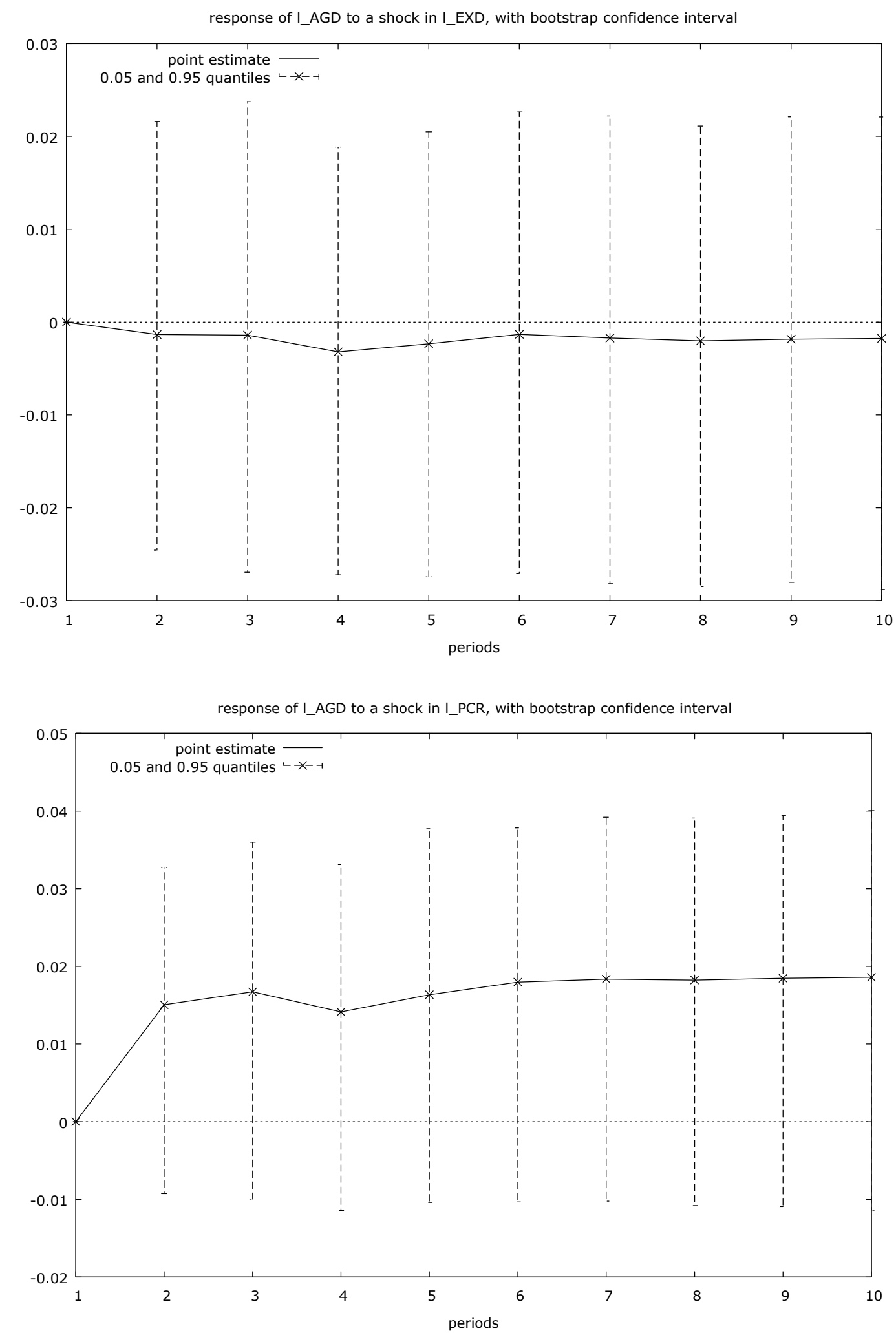

Figure 1.

\section{Summary and Recommendations}

The study established the relationship between agricultural productivity and key macroeconomic variables in 
Nigeria using short and long run model methodologies. The data properties was analyzed to determine the stationarity of time series using the Augmented Dickey-Fuller unit root test and improved ADF-GLS unit root test. The result indicates that the series used in the analysis were I(1). The results of the Cointegration test based on the Engle-Granger two-step method and Johansen's procedure indicated the existence of Cointegration between the agricultural productivity and macroeconomic variables in the country. The ECM error term had the appropriate sign and was statistically significant at $1 \%$ probability level indicating a quick convergence to equilibrium in each period, with intermediate adjustments captured by the differenced terms. The findings show that some key macroeconomic fundamentals in Nigeria's economy interact in each period to re-establish the long-run equilibrium in the agricultural productivity following a short-run random disturbance. The empirical result from the estimation of the long run agricultural productivity equation in the country revealed significant inelastic relationship with respect to the total export, external reserve, inflation rate, and external debt; while industrial capacity utilization rate and nominal exchange rate of naira to US dollar have significant positive relationship. On the other hand, short run model for agricultural productivity reveals significant negative inelastic correlation with respect to total export, external reserve, external debt and inflation rate; while per capita real GDP, industrial capacity utilization and nominal exchange rate have positive inelastic influenced. Further analysis based on the variance decomposition and impulse response analysis revalidates the earlier results and provided more facts on the behavior of agricultural productivity over time. The result reveals that most macroeconomic variables produced impulse response in the dependent variable that approaches stability in the long run periods.

The findings call for stimulation of investment opportunities in the agricultural sector so as to increase agricultural component in the country's total export. Appropriate policy package to reduce or stabilize inflation rate in the country should be implemented. Also incentives should be given to the industrial sector to boast production in order to increase capacity utilization and promote backward integration policy of the sector. Diversification of the country's economy and a drastic reduction in external debt would boost agricultural productivity in the country and enhances resource allocation to sectors in the economy. Finally, the study supports the present deregulation or market determined nominal exchange rate system in the country, because it acts as a protector to the domestic investors against unhealthy competition from cheap imports.

\section{References}

Agu, C. (2007). What does the Central Bank of Nigeria Target? An analysis of monetary policy reaction functions in Nigeria. Final report submitted to the African Economic Research Consortium, Nairobi, Kenya.

Akinbile, M., \& Adekunle, A. (2000). Land Administration in Nigeria: case studies of implementation of land use decree (Act) in OgunOndo and Oyo State of Nig. Agricultural Administration, 17(1), 21-31.

Akpan, S. B. (2010). Encouraging Youth Involvement in Agricultural Production and Processing in Nigeria. Policy Note, 29, International Food Policy Research Institute, Washington, D.C.

Akpan, S. B. (2012). Analysis of Food Crop Output Volatility in Agricultural Policy Programme Regimes in Nigeria. Developing Country Studies, 2(1), 28-35.

Akpokodje, G. (2000). The Effect of Export Earnings Fluctuations on Capital Formation in Nigeria. African Economic Research Consortium. Research paper, RP103 October 2000, Nairobi, Kenya.

Binswanger, H. (1989). The Policy Response of agriculture. In: Stanley F. and D. de Tray (Eds.), Proceedings of the World Bank Conference on Development Economics. Washington DC. pp: 121-53.

Bulanch, N., \& Verner, D. (2006). Shared Growth versus the Dual Economy Module: Evidence from Cote d'Ivoire, Ghana and Zimbabwe. African DevelopmentBank.

CBN. (2006, 2008 and 2010). Statistical Bulletin of Central Bank of Nigeria. http/www.cbn.org/out/publications.

Elliott, G. T., J. Rothenberg, \& J. C. Stock. (1996). Efficient tests for an autoregressive unit root. Econometrica 64, 813-836. http://dx.doi.org/10.2307/2171846

Eyo, E. O. (2008). Macroeconomic Environment and Agricultural Sector Growth in Nigeria. World Journal of Agricultural Sciences, 4(6), 781-786.

Fan, S., B. Omilola, V. Rhoe, \& Sheu A. S. (2008). Towards a Pro-Poor Agricultural growth strategy in Nigeria. International Food Policy Research Institute. Brief No. 1.

Garba, P. K. (2000). An Analysis of the Implementation and Stability of Nigerian Agricultural Policies. 19701993 African Economic Research Consortium Research Paper, 101. Nairobi, Kenya. 
Granger, C. W. J. (1981). Some properties of time series data and their use in econometric model specification, Journal of Econometrics, 16, 121-130. http://dx.doi.org/10.1016/0304-4076(81)90079-8

Hendry, D. F. (1995). Dynamic Econometrics, Oxford: Oxford University Press.http://dx.doi.org/10.1093/0198283164.001.0001

Hye, Q. M. A., \& Zameer J. (2011). Trade, human capital and agricultural sector growth of Pakistan economy. African Journal of Agricultural Research, 6(27), 5999-6007

Johansen, S., \& Juselius, K. (1990). Maximum likelihood estimation and inference on cointegration-with applications to the demand for money. Oxford bulletin of economicsand statistics, 52(2), 169-210.

Johansen, Soren. (1988). Statistical analysis of cointegration vectors. Journal of economic dynamics and control, $12(2 / 3), 231-254$.

Killick, T. (1990). Markets and Government in Agricultural and Industrial Adjustment. ODI Working Paper, 3, London.

Kwanashie, M., A. Garba, \& I. Ajilima. (1997). Policy Modeling in Agriculture: Testing the response of agricultural adjustment Policies in Nigeria. AERC Research Paper RP 57.

Laurenceson, J., \& Chai, J. C. H. (2003). Financial Reform and Economic Development in China. Edward Elgar, Cheltenham.

Memon, M. H, Baig W. S, \& Ali M. (2008). Causal Relationship Between Exports and Agricultural GDP in Pakistan. Available at http://mpra.ub.uni-muenchen.de/11845/.

National Population Commission (NPC). (2006). National Census Data. www.population.gov.ng/. Retrieved 10-01-2012.

Okike, I., M. A. Jabbar, V. Mayong, J. W. Smith, J. A. Akniwumi, \& S. K. Ehui. (2001). Agricultural intensification and efficiency in the West African savannahs; Evidence from northern Nigeria. Socio Economic and policy Research working paper, 33. International Livestock Research Institute.

Raufu, M. O. (2010). Pattern of Land use among selected crop farmers in Osun State. Research Journal of Soil and water management, 1(1), 1-4.

SalihTuran Katircioglu. (2006). Causality between agriculture and economic growth in a small nation under political isolation: A case from North Cyprus. International Journal of Social Economics, 33(4), 331-343. http://dx.doi.org/10.1108/03068290610651643

Shombe, N. H. (2008).Causality Relationships between Total Exports with Agricultural and Manufacturing GDP in Tanzania. IDE Discussion Paper.No. 136.

Udoh, E. U., S. B. Akpan, \& E. R. Effiong. (2011). Economic Analysis of Land Allocation Use and Intensification among Arable Crop Farmers in Uruan Local Government Area of Akwa-Ibom State, Nigeria. Journal of Economics and Sustainable Development, 2(11\&12), 1-10. 